\title{
Action of Successive Heat Treatments in Bovine Milk Fatty Acids
}

\author{
Edvaldo N. Costa, Ellen C. Q. Lacerda, Suian M. S. Santos, Carilan M. S. Santos, \\ Marcelo Franco, Robério R. Silva and Julliana I. Simionato*
}

\author{
Departamento de Estudos Básicos e Instrumentais, Universidade Estadual do Sudoeste da Bahia, \\ Praça Primavera No. 40, 45700-000 Itapetinga-BA, Brazil
}

\begin{abstract}
O estudo mostra a ação sucessiva dos tratamentos térmicos de pasteurização $\left(75^{\circ} \mathrm{C}\right.$ por $\left.15 \mathrm{~s}\right)$ e esterilização comercial por troca indireta de calor $\left(140^{\circ} \mathrm{C}\right.$ for $\left.6 \mathrm{~s}\right)$ sobre o perfil lipídico de leite bovino. Amostras de leite cru foram submetidas à pasteurização e então, à esterilização comercial (ultra-alta temperatura, UHT). A gordura de amostras de leite cru, de leite pasteurizado e de leite esterilizados comercialmente foi extraída. Após transesterificação, os ésteres metílicos dos ácidos graxos (FAMEs) foram analisados por cromatografia gasosa com detecção por ionização de chama (GC-FID). A quantificação revelou que para a maioria dos ácidos graxos (FA) encontrados não houve diferença significativa ( $p>0,05)$ entre as amostras de leite cru e leite pasteurizado. Entretanto, foram encontradas diferenças significativas para 21 dos 26 ácidos graxos analisados $(p>0,05)$ para as amostras de leite cru e de leite esterilizado, incluindo o isômero predominante no leite do ácido linoléico conjugado (CLA-c9t11). Este fato evidencia a ação sucessiva dos tratamentos térmicos no perfil lipídico do leite.
\end{abstract}

The action of successive pasteurization thermal treatments $\left(75^{\circ} \mathrm{C}\right.$ for $\left.15 \mathrm{~s}\right)$ and commercial sterilization by indirect heat exchange $\left(140{ }^{\circ} \mathrm{C}\right.$ for $\left.6 \mathrm{~s}\right)$ was analyzed on the lipid profile of bovine milk. Raw milk samples were submitted to pasteurization and then were submitted to sterilization (ultra-high temperature, UHT). The fat of raw milk, pasteurized milk and commercially sterilized milk samples was extracted. After transesterification, the fatty acid methyl esters (FAMEs) were analyzed by gas chromatography with flame ionization detector (GC-FID). The quantification of fatty acids (FA) revealed that for most of the found fatty acids there was no significant difference $(p>0.05)$ between raw milk and pasteurized milk. However, it was found significant differences for 21 of the 26 analyzed fatty acids ( $p>0.05$ ) for the raw and sterilized milks, including the predominant isomer of the conjugated linoleic acid (CLAc9t11) of the milk. This fact evidences the successive action of heat treatments on milk lipid profile.

Keywords: milk, pasteurization, commercial sterilization, conjugated linoleic acid

\section{Introduction}

Currently, there is a growing the demand for high quality dairy products, leading to a trend of gradual adaptation by the dairy industry to the needs dictated by the consumers. In this context, there are challenges such as considering the preventive role that healthy eating habits have on certain pathologies. ${ }^{1}$

As a result, nutraceutical substances present in foods have been studied. However, most compounds that show some anticarcinogenic activity are of plant origin. ${ }^{2}$ In the decade of 1980, conjugated linoleic acid isomers (CLA) were found in animal fats, with different physiological

*e-mail: jusimionato@gmail.com effects and confirmed biological activity. ${ }^{3,4}$ Isomer t10c12 acted on the redistribution of fat of the muscle, being able to reduce body fat and to increase lean body mass. ${ }^{5-7}$ Isomer c9t11 presented antitumor properties, acting in the reduction of breast cancer. ${ }^{4,8}$ These factors are causing more and more producers to seek a supplementary diet of their animals in order to increase the amount of these beneficial compounds in the final product.

Due to the characteristics of raw milk, it is essential to keep it conditioned at low temperatures and submitted to heat treatment at processing phase for the destruction of microorganisms. Pasteurization is the most widely used heat treatment by the industries. Although this process completely eliminates pathogenic bacteria from milk, it does not eliminate spores of psychrotrophic bacteria. ${ }^{9}$ 
Another widely used treatment is the commercial sterilization (ultra-high temperature, UHT), which is more advantageous than pasteurization due to its practicality of conservation and use. ${ }^{10}$

Works concern the influence of slow pasteurization on the lipid profile of human milk have been described in the literature and show that it is not changed by pasteurization. ${ }^{11}$ Similar results were also obtained in studies on the effect of the conventional heat treatment on bovine milk. ${ }^{12}$ However, no study was found about the successive action of heat treatments on the same sample. Thus, the objective of this study was to verify the effect of successive action of pasteurization and commercial sterilization (UHT) heat treatments on the fatty acids (FA) of a same sample of bovine milk.

\section{Experimental}

\section{Sampling}

Eleven milk samples from different lots were obtained from September to November 2010 in a dairy industry in Itapetinga City (Bahia, Brazil). The raw milk samples were submitted to pasteurization $\left(75^{\circ} \mathrm{C}\right.$ for $\left.15 \mathrm{~s}\right)$ and then to sterilization (ultra-high temperature, UHT). Samples were collected and immediately frozen for later duplicate analysis $(n=22)$.

\section{Analysis of fatty acids}

The analyses were carried out by Center of Chromatographic Analysis of Universidade Estadual do Sudoeste da Bahia (Itapetinga City). Lipid extraction followed the methodology proposed by Folch et al..$^{13}$ and the transesterification was carried out according to Bannon et al. ${ }^{14}$ with modifications according to Simionato et al. ${ }^{15}$

Fatty acid methyl esters (FAMEs) were analyzed by gas chromatography in Thermo model Trace-GC-Ultra, equipped with a flame ionization detector (GC-FID) and a fused silica capillary column BPX-70 (120 $\mathrm{m} \times 0.25 \mathrm{~mm}$ i.d.). The established operating parameters after checks of best resolution condition were: injector and detector temperatures, 250 and $280{ }^{\circ} \mathrm{C}$, respectively. Column temperature was set at $140{ }^{\circ} \mathrm{C}$ for $10 \mathrm{~min}$, followed by a first ramp at $15^{\circ} \mathrm{C} \mathrm{min}{ }^{-1}$ until $200{ }^{\circ} \mathrm{C}$ for $1 \mathrm{~min}$. The second ramp was at $10^{\circ} \mathrm{C} \mathrm{min}{ }^{-1}$ until $230{ }^{\circ} \mathrm{C}$ for $1 \mathrm{~min}$, the third ramp at $0.4{ }^{\circ} \mathrm{C} \mathrm{min}{ }^{-1}$ until $233{ }^{\circ} \mathrm{C}$ for $3 \mathrm{~min}$ and the fourth ramp at $0.5^{\circ} \mathrm{C} \mathrm{min}{ }^{-1}$ until $238^{\circ} \mathrm{C}$ for $2 \mathrm{~min}$. Total analysis time was $41.50 \mathrm{~min}$. Gases flow rates (White Martins) were $30 \mathrm{~mL} \mathrm{~min}^{-1}$ for hydrogen, $30 \mathrm{~mL} \mathrm{~min}^{-1}$ for nitrogen and $250 \mathrm{~mL} \mathrm{~min}^{-1}$ for synthetic air.
Injections of $1.2 \mu \mathrm{L}$ were performed in duplicate. The peak areas of FAMEs were determined by ChromQuest 4.1 software.

\section{Identification and quantification of fatty acids}

The identification of fatty acids was performed after verification of the equivalent length of the chain of peaks and comparison of retention times of samples with the standards of methyl esters of fatty acids (189-19, O-5632 and O-5626, Sigma, EUA), according to Simionato et al. ${ }^{15}$

Quantification of FA (in $\mathrm{mg} \mathrm{g}^{-1}$ of total lipids) was made in relation to the internal standard, methyl tricosanoate (23:0) (Sigma). The sample FA concentrations were calculated according to Joseph and Ackman ${ }^{16}$, using equation 1 :

$\mathrm{C}\left(\mathrm{mg} \mathrm{g}^{-1}\right)=\frac{\mathrm{A}_{\mathrm{X}} \mathrm{M}_{23: 0} \mathrm{~T}_{\mathrm{RF}}}{\mathrm{A}_{23: 0} \mathrm{M}_{\mathrm{A}} \mathrm{C}_{\mathrm{F}}}$

where $\mathrm{A}_{\mathrm{X}}=$ FAME area, $\mathrm{A}_{23: 0}=$ internal standard area, $\mathbf{M}_{23: 0}=$ internal standard mass added to the sample ( $\mathrm{mg}$ ), $\mathrm{M}_{\mathrm{A}}=$ sample mass $(\mathrm{g}), \mathrm{T}_{\mathrm{RF}}=$ theoretical response factor of FAMEs and $\mathrm{C}_{\mathrm{F}}=$ conversion factor to express the results in $\mathrm{mg}$ fatty acids per $\mathrm{g}$ total lipids (TL).

To assess the response of the FID, the theoretical response factors were calculated and the agreement verification between theoretical and experimental response factors was performed, as described by Simionato et al. ${ }^{15}$

\section{Statistical analysis}

The results were submitted to variance analysis (ANOVA) at $5 \%$ probability and means were compared by Tukey test with the software Statistical version 7.0. ${ }^{17}$

\section{Results and Discussion}

The quantification of fatty acids using internal standards has been widely applied to provide reliable results that can be easily interpreted. However, when using FID, the differential response must be considered and the correction factors must be increased. ${ }^{18}$ Thus, it is necessary to validate the used equipment to verify the agreement between the theoretical response factors $\left(\mathrm{T}_{\mathrm{RF}}\right)$ from those experimentally obtained $\left(\mathrm{E}_{\mathrm{RF}}\right)$. The ideal situation is to get results in which the error factor is close to unity, so that the results have high accuracy. After verifying the agreement between $\mathrm{E}_{\mathrm{RF}}$ and $\mathrm{T}_{\mathrm{RF}}$, the theoretical factors were used for the quantitative determinations of fatty acids, as proposed by Bannon et al. ${ }^{19}$ 


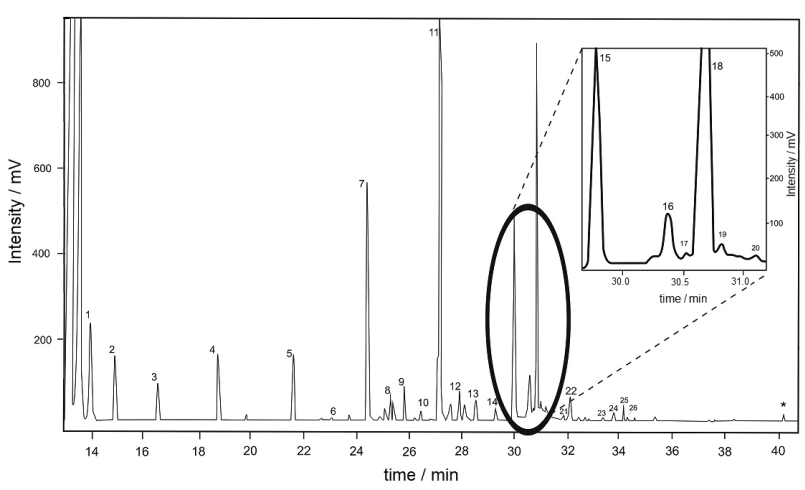

Figure 1. Gas chromatogram obtained for milk samples, the lipid profile: (1) $4: 0$, (2) 6:0, (3) 8:0; (4) 10:0, (5) 12:0, (6) 13:0, (7) 14:0, (8) 14:1, (9) $15: 0$, , (10) $15: 1$, (11) $16: 0$, (12) 16:1, (13) 17:0, (14) 17:1, (15) 18:0, (16) $18: 1 \mathrm{n}-9 \mathrm{t}$, (17) $18: 1 \mathrm{n}-7 \mathrm{t}$, , (18) $18: 1 \mathrm{n}-9$, (19) $18: 1 \mathrm{n}-7$, (20) 18:2t9t12, (21) $18: 2 \mathrm{t} 9 \mathrm{c} 12$, (22) $18: 2 \mathrm{c} 9 \mathrm{c} 12$, (23) 20:0, (24) 18:3n-3, (25) 18:2c9t11, (26) 18:2t10c12 and (*) 23:0 (standard).

Based on the equivalent chain length and the comparison with standard FA, 26 fatty acids in fat of milk were tentatively identified (Figure 1) and quantified to assess the interference of successive heat treatments.

Table 1 lists the saturated fatty acids (SFA) that were found in the samples. There was no significant difference $(\mathrm{p}>0.05)$ between raw and pasteurized milk samples for all SFAs. These results agree with Herzallah et al., ${ }^{12}$ who evaluated the influence of the low pasteurization process on the lipid profile of milk. Souza et al. ${ }^{20}$ also evaluated the composition and profile of raw and pasteurized milk fatty acids in mini dairies and found no significant difference $(p>0.05)$ for the influence of pasteurization heat treatment on raw milk.

Evaluating the commercial sterilization process by indirect heat exchange (UHT), only the obtained values for tridecanoid acid (13:0) and palmitic (16:0) SFA on different thermal treatments were not different $(p>0.05)$, evidencing that successive heat treatments have no influence in these substances. In contrast, all other analyzed SFA showed values statistically different $(\mathrm{p}>0.05)$ between raw and sterilized milk samples. This indicates that successive heat treatments influenced these substances.

From the obtained data for unsaturated fatty acids (UFA) of the analyzed samples, it was observed that, there was no statistical difference $(p>0.05)$ between raw and pasteurized milk samples, as for SFA (Table 2). Exceptions were observed for heptadec-10-enoic acid (17:1) and elaidic acid (18:1n-9t) fatty acids, with decreasing of $c a .27 \%$ (from 5.600 to $4.081 \mathrm{mg} \mathrm{g}^{-1}$ ) and $24 \%$ (from 25.51 to $19.46 \mathrm{mg} \mathrm{g}^{1}$ ), respectively, between raw and pasteurized milk samples. However, as noted for SFA, most analyzed UFA presented statistically different values $(p>0.05)$ between raw and sterilized milk samples, indicating the action of successive heat treatments on these FA. Exceptions were observed for vaccenic (18:1n-7t) and trans-9-cis-12-octadienoic (18:2t9c12) acids and t10c12 isomer of the conjugated linoleic acid (18:2t10c12), in which heat treatment action was not statistically verified.

There was a significant reduction ( $c a .21 .80 \%$ ) between raw and UHT milk samples for CLAc9t11 (from 10.18 to $\left.7.96 \mathrm{mg} \mathrm{g}^{-1}\right)$. Herzallah et al. ${ }^{12}$ found CLA levels in pasteurized milk (according to high temperature, short time (HTST) and low temperature, long time (LTLT) processes) lower than those found in raw milk. According to the same author, the trend in reduction of CLA could be attributed to an oxidation process, resulting in hydroperoxides that could cause the conversion or degradation of CLA. ${ }^{12}$ This study evidences and confirms the action of successive heat treatments on this fatty acid.

Table 1. Saturated fatty acids $\left(\mathrm{mg} \mathrm{g}^{-1}\right)$ of lipids for raw, pasteurized and sterilized milk samples

\begin{tabular}{|c|c|c|c|c|c|}
\hline Fatty acid ${ }^{\mathrm{a}}$ & & Raw milk / (mg g $\left.{ }^{-1}\right)$ & Pasteurized milk / $\left(\mathrm{mg} \mathrm{g}^{-1}\right)$ & Sterilized milk / $\left(\mathrm{mg} \mathrm{g}^{-1}\right)$ & $\mathrm{VC}^{\mathrm{b}}$ \\
\hline Butyric & $4: 0$ & $34.25^{\mathrm{A}}$ & $31.38^{\mathrm{AB}}$ & $23.36^{\mathrm{B}}$ & 38.59 \\
\hline Caproic & $6: 0$ & $21.29^{\mathrm{A}}$ & $19.93^{\mathrm{A}}$ & $14.70^{\mathrm{B}}$ & 37.53 \\
\hline Caprylic & $8: 0$ & $11.77^{\mathrm{A}}$ & $10.81^{\mathrm{AB}}$ & $8.39^{\mathrm{B}}$ & 37.99 \\
\hline Capric & 10:0 & $22.46^{\mathrm{A}}$ & $20.71^{\mathrm{AB}}$ & $17.09^{\mathrm{B}}$ & 32.68 \\
\hline Lauric & $12: 0$ & $25.52^{\mathrm{A}}$ & $23.03^{\mathrm{AB}}$ & $19.35^{\text {В }}$ & 30.98 \\
\hline Tridecanoic acid & 13:0 & $0.84^{\mathrm{A}}$ & $0.98^{\mathrm{A}}$ & $0.64^{\mathrm{B}}$ & 61.53 \\
\hline Myristic & 14:0 & $93.78^{\mathrm{A}}$ & $82.31^{\mathrm{AB}}$ & $72.60^{\mathrm{B}}$ & 29.30 \\
\hline Pentadecenoic & $15: 0$ & $13.80^{\mathrm{A}}$ & $12.03^{\mathrm{AB}}$ & $10.90^{\mathrm{B}}$ & 27.40 \\
\hline Palmitic & $16: 0$ & $251.70^{\mathrm{A}}$ & $222.40^{\mathrm{A}}$ & $198.60^{\mathrm{B}}$ & 24.82 \\
\hline Margaric & $17: 0$ & $8.07^{\mathrm{A}}$ & $7.08^{\mathrm{AB}}$ & $6.71^{\mathrm{B}}$ & 25.00 \\
\hline Stearic & 18:0 & $103.90^{\mathrm{A}}$ & $89.38^{\mathrm{AB}}$ & $83.41^{\mathrm{B}}$ & 22.16 \\
\hline Arachidic & 20:0 & $1.66^{\mathrm{A}}$ & $1.41^{\mathrm{AB}}$ & $1.310^{\mathrm{B}}$ & 26.73 \\
\hline
\end{tabular}

${ }^{a}$ Usual nomenclature; ${ }^{b}$ variation coefficient; means in the same row followed by different letters differ by Tukey test $(\mathrm{p}>0.05)$. 
Table 2. Mono and polyunsaturated fatty acids $\left(\mathrm{mg} \mathrm{g}^{-1}\right)$ of lipids for raw, pasteurized and sterilized milk samples

\begin{tabular}{|c|c|c|c|c|c|}
\hline Fatty acid ${ }^{a}$ & & $\begin{array}{l}\text { Raw milk / } \\
\left(\mathrm{mg} \mathrm{g}^{-1}\right)\end{array}$ & $\begin{array}{l}\text { Pasteurized milk / } \\
\qquad\left(\mathrm{mg} \mathrm{g}^{-1}\right)\end{array}$ & $\begin{array}{l}\text { Sterilized milk / } \\
\qquad\left(\mathrm{mg} \mathrm{g}^{-1}\right)\end{array}$ & $\mathrm{VC}^{\mathrm{b}}$ \\
\hline Myristoleic & $14: 1$ & $8.991^{\mathrm{A}}$ & $7.953^{\mathrm{AB}}$ & $7.01^{\mathrm{B}}$ & 26.25 \\
\hline Palmitoleic & $16: 1$ & $12.13^{\mathrm{A}}$ & $11.01^{\mathrm{AB}}$ & $9.52^{\mathrm{B}}$ & 30.15 \\
\hline Heptadec-10-enoic acid & $17: 1$ & $5.60^{\mathrm{A}}$ & $4.081^{\mathrm{B}}$ & $3.78^{\mathrm{b}}$ & 38.96 \\
\hline Elaidic & $18: 1 n-9 t$ & $25.51^{\mathrm{A}}$ & $19.46^{\mathrm{B}}$ & $18.48^{\mathrm{B}}$ & 29.13 \\
\hline Oleic & $18: 1 n-9 c$ & $216.70^{\mathrm{A}}$ & $187.50^{\mathrm{AB}}$ & $170.60^{\mathrm{B}}$ & 23.62 \\
\hline Vaccenic acid & $18: 1 \mathrm{n}-7 \mathrm{t}$ & $9.47^{\mathrm{A}}$ & $8.47^{\mathrm{A}}$ & $7.84^{\mathrm{B}}$ & 55.75 \\
\hline Cis vaccenic acid & $18: 1 \mathrm{n}-7 \mathrm{c}$ & $5.28^{\mathrm{A}}$ & $3.58^{\mathrm{AB}}$ & $2.67^{\mathrm{B}}$ & 76.99 \\
\hline Linolelaidic & $18: 2 n-6 t$ & $5.56^{\mathrm{A}}$ & $4.47^{\mathrm{AB}}$ & $3.66^{\mathrm{B}}$ & 52.86 \\
\hline Trans- -9 , cis- 12 acid octadienoic & $18: 2 \mathrm{t} 9 \mathrm{c} 12$ & $2.54^{\mathrm{A}}$ & $1.99^{\mathrm{A}}$ & $2.26^{\mathrm{A}}$ & 37.04 \\
\hline Gamma-linoleic & $18: 2 n-6$ & $8.01^{\mathrm{A}}$ & $6.96^{\mathrm{AB}}$ & $6.41^{\mathrm{B}}$ & 21.30 \\
\hline Alpha-linolenic & $18: 3 n-3$ & $3.82^{\mathrm{A}}$ & $3.381^{\mathrm{AB}}$ & $3.10^{\mathrm{B}}$ & 24.78 \\
\hline Dihomo-gamma-linolenic acid & $20: 3 n-6$ & $11.99^{\mathrm{A}}$ & $10.33^{\mathrm{AB}}$ & $9.26^{\mathrm{B}}$ & 25.03 \\
\hline Conjugated linoleic acid & CLAc9t11 & $10.18^{\mathrm{A}}$ & $8.82^{\mathrm{AB}}$ & $7.96^{\mathrm{B}}$ & 24.02 \\
\hline Conjugated linoleic acid & CLAt10c12 & $0.78^{\mathrm{A}}$ & $0.81^{\mathrm{A}}$ & $0.54^{\mathrm{A}}$ & 57.16 \\
\hline
\end{tabular}

${ }^{a}$ Usual nomenclature; ${ }^{b}$ variation coefficient; means in the same row followed by different letters differ by Tukey test $(\mathrm{p}>0.05)$.

Figure 2 shows octadienoic acid profiles to raw, pasteurized and sterilized milk samples. It is evidenced the significant difference between raw and UHT milks for CLAc9t12 and 18:2c9c12 and no difference between raw and UHT milks for CLAt10c12.

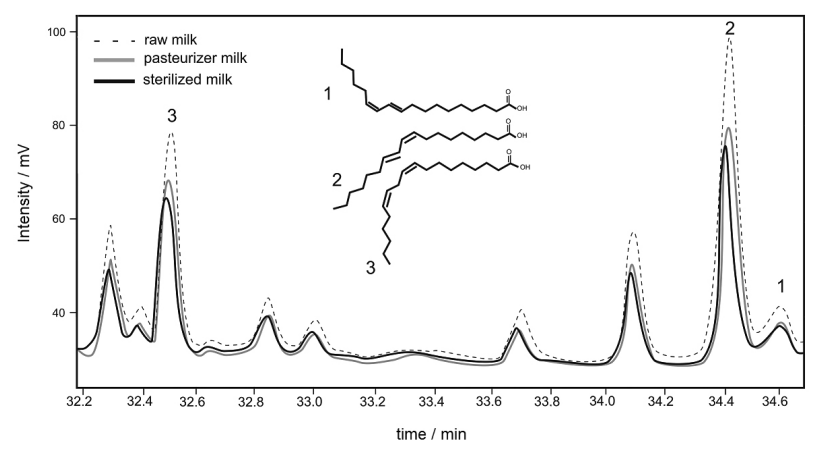

Figure 2. Gas chromatograms obtained for (---) raw, (-) pasteurized and (-) sterilized milk samples, the octadienoic acid profiles: (1) CLA(t10c12), (2) CLA(c9t11) and (3)18:2c9c12.

Fanti et al. ${ }^{21}$ report that CLA content in fat milk is usually between 0.3 and $1.0 \%$. Data from this study are higher than these, but close to those found by Kelsey et al. ${ }^{22}$ The found difference in conjugated linoleic acid contents may be caused by season, feed, breed, food supplied to the animal, lactation phase and thermal processing. ${ }^{23}$

Table 3 shows the sums of saturated (4:0, 6:0, 8:0, 10:0, 12:0, 13:0, 14:0, 15:0, 16:0, 17:0, 18:0, 20:0), monounsaturated $(14: 1,16: 1,17: 1,18: 1 \mathrm{n} 9 \mathrm{t}, 18: 1 \mathrm{n} 9 \mathrm{c}$, $18: 1 \mathrm{n} 7 \mathrm{t}, 18: 1 \mathrm{n} 7 \mathrm{c})$ and polyunsaturated $(18: 2 \mathrm{n} 6 \mathrm{t}, 18: 2 \mathrm{t} 9 \mathrm{c} 12$, 18:2n-6, 18:3n-3, CLAc9t11, CLAt10c12, 20:3n-6) fatty acids, the relation between polyunsaturated and saturated fatty acids (AGPI/AGS), the sums of omega-3 (18:3n-3, 20:3n-3) and omega-6 (18:2n-6, 20:3n-6) fatty acid series and the relation between the fatty acids of these series $(n-6 / n-3)$.

The same trend previously reported was observed in the present article, i.e., there are no significant differences ( $p>0.05$ ) for the sums of saturated, monounsaturated and polyunsaturated fatty acids and omegas 6 and 3 between raw and pasteurized milks. However, significant difference was found $(p>0.05)$ between raw and sterilized milk samples. Successive action of pasteurization and sterilization treatments generally decreased the fatty acids in milk, but not to the point of interfering in the ratios between omegas 3 and 6 and between saturated and polyunsaturated fatty acids, as evidenced by the statistical similarity of the results.

The ratios between the omega- 6 and omega- 3 fatty acids in the samples that were subjected to different heat treatments were equal to $2.10,1.97$ and 2.07 for raw, pasteurized and commercially sterilized milks, respectively. Simopoulos ${ }^{24}$ suggests that this ratio cannot be over than 4 . The United Kingdom Department of Health ${ }^{25}$ suggests that the intake ratio of omega- 6 and omega- 3 is between 5 and 10. The values from this study show that milk despite of presenting high levels of saturated fatty acids is still a great source of essential fatty acids. Results indicate that there was no significant difference between raw, pasteurized and UHT milks in the ratio of $n-6 / n-3$. Moreover, there were no significant differences for most analyzed fatty acids, as 
Table 3. Totals of saturated, monounsaturated and unsaturated fatty acids; ratio unsaturated/saturated fatty acids, omega-3, omega-6 and ration between omega- 6 and omega-3 ( $\left.\mathrm{mg} \mathrm{g}^{-1}\right)$ of lipids for raw, pasteurized and sterilized milk

\begin{tabular}{|c|c|c|c|c|}
\hline Fatty Acid ${ }^{\mathrm{a}}$ & Raw milk / $\left(\mathrm{mg} \mathrm{g}^{-1}\right)$ & Pasteurized milk / $\left(\mathrm{mg} \mathrm{g}^{-1}\right)$ & Sterilized milk / $\left(\mathrm{mg} \mathrm{g}^{-1}\right)$ & $\mathrm{VC}^{\mathrm{b}}$ \\
\hline Saturated & $589.10^{\mathrm{A}}$ & $521.40^{\mathrm{AB}}$ & $457.10^{\mathrm{B}}$ & 26.06 \\
\hline Monounsaturated & $283.60^{\mathrm{A}}$ & $242.10^{\mathrm{AB}}$ & $219.90^{\mathrm{B}}$ & 23.53 \\
\hline Polyunsaturated & $33.77^{\mathrm{A}}$ & $28.85^{\mathrm{AB}}$ & $26.16^{\mathrm{B}}$ & 24.52 \\
\hline $\mathrm{PUFA} / \mathrm{SFA}^{\mathrm{c}}$ & $0.06^{\mathrm{A}}$ & $0.05^{\mathrm{A}}$ & $0.06^{\mathrm{A}}$ & 13.28 \\
\hline$n-3$ & $4.60^{\mathrm{A}}$ & $4.19^{\mathrm{AB}}$ & $3.65^{\mathrm{B}}$ & 24.86 \\
\hline$n-6$ & $9.07^{\mathrm{A}}$ & $7.86^{\mathrm{AB}}$ & $7.32^{\mathrm{B}}$ & 20.03 \\
\hline$n-6 / n-3$ & $2.10^{\mathrm{A}}$ & $1.97^{\mathrm{A}}$ & $2.07^{\mathrm{A}}$ & 10.72 \\
\hline
\end{tabular}

${ }^{a}$ Usual nomenclature; ${ }^{b}$ variation coefficient; ' ratio polyunsaturated/saturated fatty acids; means in the same row followed by different letters differ by Tukey test $(\mathrm{p}>0.05)$.

confirmed by Ford and Thompson. ${ }^{26}$ According to these authors, there are no alterations of nutritional importance on lipid content after UHT processing, although there might be some unsaturated fatty acid loss in milk lipids. ${ }^{26}$ The results from that study indicate that in milk obtained from animals fed with special diets (aimed to increase such substances), the thermal processing will not negatively affect the quality of the final product as to the presence of essential fatty acids.

However, results also show that, when a final product rich in CLA is desirable (either by animal supplementation or direct addition), one must be careful with the processing since it was found significant differences after successive heat treatments, the evidence of the reduction of the isomer c9t11. The isomer c9t11 according to Kelsey et al. ${ }^{22}$ is the most abundant, corresponding to 75 to $90 \%$ of total CLA in milk fat.

\section{Conclusions}

Pasteurization does not significantly alter the quality and quantity of fatty acids in milk. However, significant differences can be found when raw milk passes through successive heat treatments of pasteurization and commercial sterilization. These differences were found in 21 of the 26 analyzed fatty acids, including the predominant isomer of conjugated linoleic acid (CLA) in milk. This evidenced the action of successive heat treatments on the lipid profile of milk.

\section{Supplementary Information}

Experimental $\left(\mathrm{E}_{\mathrm{RF}}\right)$ and theoretical $\left(\mathrm{T}_{\mathrm{RF}}\right)$ correction factors and error factor $\left(\mathrm{E}_{\mathrm{F}}\right)$ of the TRACE GC Ultra Gas Chromatograph Thermo Scientific are available free of charge as PDF file at http://jbcs.sbq.org.br.

\section{Acknowledgements}

The authors would like to thank Coordenação de Aperfeiçoamento de Pessoal de Nível Superior (CAPES), Conselho Nacional de Desenvolvimento Científico e Tecnológico (CNPq) and Fundação de Apoio à Pesquisa do Estado da Bahia (FAPESB) for financial support.

\section{References}

1. Reis, G. L.; Alves, A. A.; Lana, A. M. Q.; Coelho, S. G.; de Souza, M. R.; Cerqueira, M. M. O. P.; Penna, C. F. A. M.; Mendes, E. D. M.; Ciênc. Rural 2007, 37, 1134.

2. Santos, F. L.; Lana, R P.; Silva, M. T. C.; Biotecnologia Ciênc. Desenvolv. 2002, 24, 42.

3. Seçkin, A. K.; Gursoy, O.; Kinik, O.; Akbulut, N.; LWT--Food Sci. Tech. 2005, 38, 909.

4. Sieber, R.; Collomb, M.; Aeschlimann, A.; Jelen, P.; Eyer, H.; Int.Dairy J. 2004, 14, 1.

5. Fuente, M. A.; Luna, P.; Juárez, M.; TrAC, Trends Anal. Chem. 2006, 25, 917.

6. Mourão, D. M.; Monteiro, J. B. R.; Costa, N. M. B.; Stringheta, P. C.; Minin, V. P. R.; Dias, C. M. G. C.; Braz. J. Nutr. 2005, 18, 391.

7. Roach, J. A. G.; Mossoba, M. M.; Yurawecz, M. P.; Kramer, J. K. G.; Anal. Chim. Acta 2002, 465, 207.

8. Ou, L.; Ip, C.; Lisafeld, B.; Ip, M. M.; Biochem. Biophys. Res. Commun. 2007, 356, 1044.

9. Pereda, J. A.; Jaramillo, D. P.; Quevedo, J. M.; Ferragut, V.; Guamis, B.; Trujillo, A. J.; Int. Dairy J. 2008, 18, 826.

10. Muir, D. D.; J. Soc. Dairy Techol. 1996, 49, 24.

11. Moltó-Puigmartí, C.; Permanyer, M.; Castellote, A. I.; López-Sabater, M. C.; Food Chem. 2011, 124, 697.

12. Herzallah, S. M.; Humeid, M. A.; Al-Ismail, K. M.; J. Dairy Sci. 2005, 88, 1301.

13. Folch, J.; Lees, M.; Stanley, G. H. S.; J. Biol. Chem. 1957, 226, 497. 
14. Bannon, C. D.; Craske, J. D.; Hai, N. T.; Harper, N. L.; O'Rourke, K. L.; J. Chromatogr., A 1982, 247, 71

15. Simionato, J. I.; Garcia, J. C.; dos Santos, G. T.; Oliveira, C. C.; Visentainer, J. V.; Souza, N. E.; J. Braz. Chem. Soc. 2010, 21, 520 .

16. Joseph, J. D.; Ackman, R. G.; J. AOAC Int. 1992, 75, 488.

17. Statsoft, Inc.; Statistica 7.0 Software; Tucksa: USA, 2005.

18. Ackman, R. G.; Progr. Chem. Fats Other Lipids 1972, 12, 165.

19. Bannon, C. D.; Craske, J. D.; Hilliker, A. E.; J. Am. Oil Chem. Soc. 1986, 63, 105.

20. Souza, L.G.; Santos, G. T.; Damasceno, J. C.; Matsushita, M.; Sakaguti, E. S.; Ribas, N. P.; Villalba, R. G.; Acta Sci. Anim. Sci. 2003, 25, 331.

21. Fanti, M. G. N.; Almeida, K. E.; Rodrigues, A. M.; Silva, R. C.; Florence, C. R.; Gioielli, L. A.; Oliveira, M. N.; Ciênc. Tecnol. Alim. 2008, 28, 259.
22. Kelsey J. A.; Corl, B. A.; Collier, R. J.; Bauman, D. E.; J. Dairy Sci. 2003, 86, 2588.

23. Prandini, A.; Sigolo, S.; Tansini, G.; Brogna, N.; Piva, G.; J. Food Compos. Anal. 2007, 20, 472.

24. Simopoulos, A. P.; Biomed. Pharmacoth. 2006, 60, 502.

25. United Kingdom Department of Health, Committee on Medical Aspects of Food Policy; Nutritional Aspects of Cardiovascular Disease, Report on Health and Social Subjects, No. 46; HMSO: London, 1994.

26. Ford, J.E.; Thompson, S. Y.; In: International Dairy Federation. New monograph on UHT milk. Brussels, 1981.

Submitted: June 27, 2011

Published online: September 13, 2011 


\title{
Action of Successive Heat Treatments in Bovine Milk Fatty Acids
}

\author{
Edvaldo N. Costa, Ellen C. Q. Lacerda, Suian M. S. Santos, Carilan M. S. Santos, \\ Marcelo Franco, Robério R. Silva and Julliana I. Simionato* \\ Departamento de Estudos Básicos e Instrumentais, Universidade Estadual do Sudoeste da Bahia, \\ Praça Primavera No. 40, 45700-000 Itapetinga-BA, Brazil
}

Table S1. Experimental $\left(\mathrm{E}_{\mathrm{RF}}\right)$ and theoretical $\left(\mathrm{T}_{\mathrm{RF}}\right)$ correction factors and error factor $\left(\mathrm{E}_{\mathrm{F}}\right)$ for the gas chromatograph thermo trace-GC-ultra

\begin{tabular}{lccc}
\hline Fatty acids & $\mathrm{E}_{\mathrm{RF}}$ & $\mathrm{T}_{\mathrm{RF}}$ & $\mathrm{EF}$ \\
\hline $12: 0$ & 1.224 & 1.114 & 1.099 \\
$14: 0$ & 1.032 & 1.080 & 0.956 \\
$16: 0$ & 0.961 & 1.055 & 0.912 \\
$18: 0$ & 0.925 & 1.035 & 0.894 \\
$18: 1$ & 0.914 & 1.028 & 0.889 \\
$18: 2$ & 1.012 & 1.021 & 0.991 \\
$18: 3$ & 1.136 & 1.014 & 1.121 \\
$20: 0$ & 0.900 & 1.019 & 0.883 \\
$20: 3$ & 1.094 & 0.999 & 1.094 \\
\hline
\end{tabular}

$\mathrm{E}_{\mathrm{RF}}=$ experimental correction factor; $\mathrm{T}_{\mathrm{RF}}=$ theoretical correction factor; $\mathrm{E}_{\mathrm{F}}=$ error factor. 